\title{
Pancreatic cancer cell apoptosis is induced by a proteoglycan extracted from Ganoderma lucidum
}

\author{
XIAO WU ${ }^{1}$, LIPING JIANG ${ }^{1}$, ZENG ZHANG ${ }^{2}$, YANMING HE ${ }^{2}$, YILONG TENG ${ }^{1}$, JIAQI LI ${ }^{1}$, \\ SHILIN YUAN ${ }^{1}$, YANNA PAN ${ }^{1}$, HAOHUI LIANG $^{1}$, HONGJIE YANG $^{2}$ and PING ZHOU ${ }^{1}$

\begin{abstract}
${ }^{1}$ State Key Laboratory of Molecular Engineering of Polymers, Department of Macromolecular Science, Fudan University, Shanghai University of Traditional Chinese Medicine, Shanghai 200437, P.R. China
\end{abstract} \\ Shanghai 200433; ${ }^{2}$ Department of Endocrinology, Yueyang Hospital of Integrated Traditional Chinese and Western Medicine,
}

Received April 18, 2020; Accepted September 28, 2020

DOI: $10.3892 / 01.2020 .12295$

\begin{abstract}
The Traditional Chinese Medicine, Ganoderma lucidum, has been widely used for its immunity-related and anti-cancer effects. Fudan-Yueyang-Ganoderma lucidum (FYGL) is a proteoglycan, extracted from Ganoderma lucidum, that has shown safe anti-diabetic activity in vivo. The present study demonstrated that FYGL could selectively inhibit the viability of PANC-1 and BxPC-3 pancreatic cancer cells in a dose dependent manner, but not in Mia $\mathrm{PaCa}-2$ pancreatic cancer cells and HepG2 liver cancer cells. In addition, FYGL could inhibit migration and colony formation, and promote apoptosis in PANC-1 cells, but not in Mia PaCa- 2 cells. Further investigation into the underlying mechanism revealed that FYGL could inhibit the expression level of the Bcl-2 protein in PANC-1 cells, but not in Mia PaCa-2 cells, leading to an increase in reactive oxygen species (ROS) and a reduction in the mitochondrial membrane potential and cell apoptosis. The increased ROS also promoted the formation of autophagosomes, along with an increase in the microtubule-associated protein light chain 3 II/I ratio. However, FYGL halted autophagy by preventing the autophagosomes from entering the lysosomes. The inhibition of autophagy increased the accumulation of defective mitochondria, as well as the production of ROS. Taken together, the processes of ROS regulation and autophagy inhibition promoted apoptosis of PANC-1 cells through the caspase-3/cleaved caspase-3 cascade. These results indicated that FYGL could be potentially used as an anti-cancer agent in the treatment of pancreatic cancer.
\end{abstract}

Correspondence to: Dr Ping Zhou, State Key Laboratory of Molecular Engineering of Polymers, Department of Macromolecular Science, Fudan University, 220 Handan Road, Shanghai 200433, P.R. China

E-mail: pingzhou@fudan.edu.cn

Key words: Ganoderma lucidum, proteoglycan, pancreatic cancer, apoptosis, reactive oxygen species, autophagy

\section{Introduction}

Pancreatic cancer is a highly malignant tumor of the digestive system. In the United States, in 2018, an estimated 56,770 cases of pancreatic cancer occurred, and 45,750 patients succumbed to the disease (1). Pancreatic cancer is one of the most fatal types of cancer, for its mortality rates closely parallels its incidence rates (2). Most patients have obvious symptoms, particularly in the advanced stage of pancreatic cancer (2). Gemcitabine is a widely used drug for the treatment of pancreatic cancer, to improve the surgical success ratio. However, its serious side effects attenuate its efficacy, and cause harm to patients (3). Therefore, it is crucial to identify an efficacious drug, with fewer serious side effects, for the treatment of pancreatic cancer.

Ganoderma lucidum is a Traditional Chinese Medicine. Several biological activities and pharmacological functions of polysaccharides, proteins, and triterpenoids, found in Ganoderma lucidum, have been reported, including the defense of tumors, management of blood sugar levels, modulation of immunity, and protection of hepatocytes (4). In our previous study a proteoglycan, Fudan-Yueyang Ganoderma lucidum (FYGL) was extracted from the Ganoderma lucidum fruiting body (5). FYGL is composed of both proteins and polysaccharides, and its molecular weight is $2.6 \times 10^{5}$. FYGL is an amphiphilic hyperbranched proteoglycan consisting of hydrophilic polysaccharides (4 saccharide units) and lipophilic protein moieties (17 amino acids), with a saccharide:protein ratio of 77:17 (6). Our previous study demonstrated that, FYGL could efficiently and safely manage blood sugar levels in vivo, and affect multiple signaling pathways for insulin regulation $(5,7,8)$.

Oxidative stress is crucial for both anticancer effects and cancer development (9). Excessive reactive oxygen species (ROS) can damage the cancer cell structures, including lipids, proteins, and DNA, resulting in cancer cell death, apoptosis and autophagy $(10,11)$. Furthermore, high levels of ROS, and the resultant oxidative damage, can decrease the mitochondrial membrane potential (MMP), leading to cancer cell death $(12,13)$. However, the production of ROS by mammalian mitochondria has been associated with multiple pathologies, including neurodegenerative diseases (14), diabetes (15), 
cancer (16) and premature aging (17). Therefore, the regulation of ROS at a suitable concentration in the body is crucial for maintaining health. In addition, the autophagy of cancer cells is a catabolic pathway for supporting metabolism in response to starvation, and for removing damaged proteins and organelles in response to stress (18). Autophagy maintains mitochondrial metabolic function, which is beneficial for the growth of aggressive cancers (19); however, pharmacological inhibition of autophagy can cause the accumulation of defective mitochondria, and consequently lead to metabolomic issues (20). Cell autophagy is essential for pancreatic cancer activity and it has been found that inhibition of autophagy in cancer cells through genetically and pharmacologically increasing ROS; therefore, damaging DNA, is an alternative method of inducing apoptosis in pancreatic cancer cells $(21,22)$.

In the present study, the anti-pancreatic cancer ability of FYGL was investigated and to compare its selectivity in 3 different pancreatic cancer cell lines (PANC-1, BxPC-3 and $\mathrm{Mia} \mathrm{PaCa}-2)$, as well as in the HepG2 hepatic cell line. In addition, the effect of FYGL on cell migration, colony formation, ROS production, and cell autophagy were also investigated. The results indicated that FYGL was effective at inducing apoptosis in the PANC-1 cells, by increasing ROS and inhibiting autophagy.

\section{Materials and methods}

Cell lines and reagents. FYGL was extracted from Ganderma lucidum in our laboratory (5). The human pancreatic cancer cell line, PANC-1, and the human liver cancer cell line, HepG2, were obtained from Procell Life Science \& Technology Co., Ltd., while the human pancreatic cancer cell line, Mia PaCa-2, was donated by Professor Wuli Yang (Fudan University, Shanghai, China). The human pancreatic cancer cell line, BxPC-3, was donated by Doctor Yiqun Ma (Zhongshan Hospital, Shanghai, China). The PANC-1, Mia PaCa-2 and HepG2 cells were cultured in DMEM (Gibco; Thermo Fisher Scientific, Inc.) supplemented with 10\% FBS (Gibco; Thermo Fisher Scientific, Inc.), $1 \%$ penicillin/streptomycin and $1 \%$ L-glutamine (Thermo Fisher Scientific, Inc.). The BxPC-3 cells were cultured in RPMI-1640 (Gibco; Thermo Fisher Scientific, Inc.) supplemented with $10 \% \mathrm{FBS}, 1 \%$ penicillin/streptomycin and $1 \%$ L-glutamine. Cells were incubated at $37^{\circ} \mathrm{C}$ in a humidified atmosphere with $5 \% \mathrm{CO}_{2}$. The following antibodies: Caspase-3 (dilution 1:1,000; cat. no. 9662S), cleaved-caspase-3 (dilution 1:1,000; cat. no. 9661S), Bcl-2 (dilution 1:1,000; cat. no. 4223S), P62 (dilution 1:1,000; cat. no. 39749S), LC3A/B (dilution 1:1,000; cat. no. 12741S), $\beta$-actin (dilution 1:1,000; cat. no. 4970S), GAPDH (dilution 1:1,000; cat. no. 5174S), and HRP-conjugated secondary anti-rabbit (dilution 1:2,000; cat. no. 7074S) were all purchased from Cell Signaling Inc.

Cell viability assay. The cells were seeded in 96-well plates at $37^{\circ} \mathrm{C}$ in a humidified atmosphere with $5 \% \mathrm{CO}_{2}$, at a density of $5 \times 10^{4}$ cells/well. After $24 \mathrm{~h}$, the cells in each well were treated with FYGL at a concentration range of $0-1,000 \mu \mathrm{g} / \mathrm{ml}$, and gemcitabine (Eli Lilly and Company) as a positive control at a concentration range of 5-20 $\mu \mathrm{M}$ for 24 and $48 \mathrm{~h}$, then, $10 \mu \mathrm{l}$ Cell Counting Kit-8 (CCK-8) reagent (Shanghai Yeasen Biotechnology Co., Ltd.) was added into each well. The absorbance was measured at $450 \mathrm{~nm}$, using a microplate reader (Cytation 3; BioTek Instruments, Inc.), 1-4 h later.

Confocal microscopy analysis. The cells were seeded in cell culture dishes (Wuxi NEST Biotechnology Co., Ltd.) at a density of $1 \times 10^{5}$ cells/well at $37^{\circ} \mathrm{C}$ in a humidified atmosphere with $5 \% \mathrm{CO}_{2}$. After treatment with 0 (control) and $150 \mu \mathrm{g} / \mathrm{ml}$ FYGL, the cells were fixed with $4 \%$ paraformaldehyde (PFA) for $10 \mathrm{~min}$ at $37^{\circ} \mathrm{C}$, then permeabilized with $0.3 \%$ Triton $\mathrm{X}-100$ (Sinopharm Chemical Reagent Co., Ltd.). FYGL was stained with a green fluorescent agent, fluorescein isothiocyanate (FITC), and the cell nucleus and cytoskeleton were stained with a blue fluorescent agent, 4',6-diamidino-2-phenylindole (DAPI), and a red fluorescent agent, rhodamine-labeled phalloidin (all from Shanghai Yeasen Biotech Co., Ltd.), respectively for $10 \mathrm{~min}$ at $37^{\circ} \mathrm{C}$. Images were obtained using a laser scanning confocal microscope (magnification, x100; LSCM; Nikon C2+; Nikon Corporation).

Wound healing assay. The cells were seeded $\left(5 \times 10^{5}\right.$ cells/well) in 6-well plates at $37^{\circ} \mathrm{C}$ in a humidified atmosphere with $5 \%$ $\mathrm{CO}_{2}$, and the cell monolayer was scratched with a pipette tip when the cells grew to a single layer. Following which, the cells were treated with FYGL at a concentration range of $0-1,000 \mu \mathrm{g} / \mathrm{ml}$ in DMEM medium with 3\% FBS for $48 \mathrm{~h}$. Cell images were obtained using an inverted optical microscope (Nikon ECLIPSE Ts2; Nikon Corporation) to observe the migration of the cells across the wound (magnification, $\mathrm{x} 4$ ). ImageJ software (v1.51j8; National Institutes of Health) was used for digital analysis of the wound healing area.

Colony viability assay. The cells were seeded in 6-well culture plates at $37^{\circ} \mathrm{C}$ in a humidified atmosphere with $5 \% \mathrm{CO}_{2}$, at a density of 200 cells/well and incubated for $24 \mathrm{~h}$. Then, the cells in each well were treated with FYGL at a concentration range of $0-1,000 \mu \mathrm{g} / \mathrm{ml}$ for 12 days. All colonies were fixed with $4 \%$ PFA for $10 \mathrm{~min}$ at $37^{\circ} \mathrm{C}$, and washed with PBS (Sangon Biotech Co., Ltd.) subsequently, the cells in each well were stained with a purple dye, giemsa (Shanghai Yeasen Biotechnology Co., Ltd.) for $10 \mathrm{~min}$ at $37^{\circ} \mathrm{C}$. Cell images were obtained using an optical camera (magnification, $\mathrm{x} 1$; Sony $\alpha 6400$; Sony Corporation).

Cell apoptosis assay. The percentage of apoptotic cells was determined using an Annexin V-FITC/PI kit (Shanghai Yeasen Biotechnology, Co., Ltd.). Cells were seeded in 6-well plates, at a density of $5 \times 10^{5}$ cells/well. After incubation for $24 \mathrm{~h}$, the cells were treated with FYGL at a concentration range of $0-500 \mu \mathrm{g} / \mathrm{ml}$ for $24 \mathrm{~h}$ and harvested using $0.25 \%$ trypsin (Sangon Biotech Co., Ltd.), then the cells were incubated with $5 \mu \mathrm{l}$ Annexin V-FITC and $10 \mu \mathrm{l}$ PI working solution for $30 \mathrm{~min}$ at $37^{\circ} \mathrm{C}$. Finally, the stained cells were analyzed using flow cytometry (Beckman Coulter, Inc.), and the data were analyzed using FlowJo software (version 10.4; BD Biosciences).

Measurement of intracellular ROS levels. The fluorescent agent, 2,7-dichlorodi-hydrofluorescein diacetate (DCFH-DA; Shanghai Yeasen Biotech Co., Ltd.) was used to investigate ROS production. The cells were seeded in 6 -well plates at $37^{\circ} \mathrm{C}$ in a humidified atmosphere with $5 \% \mathrm{CO}_{2}$, at a density 

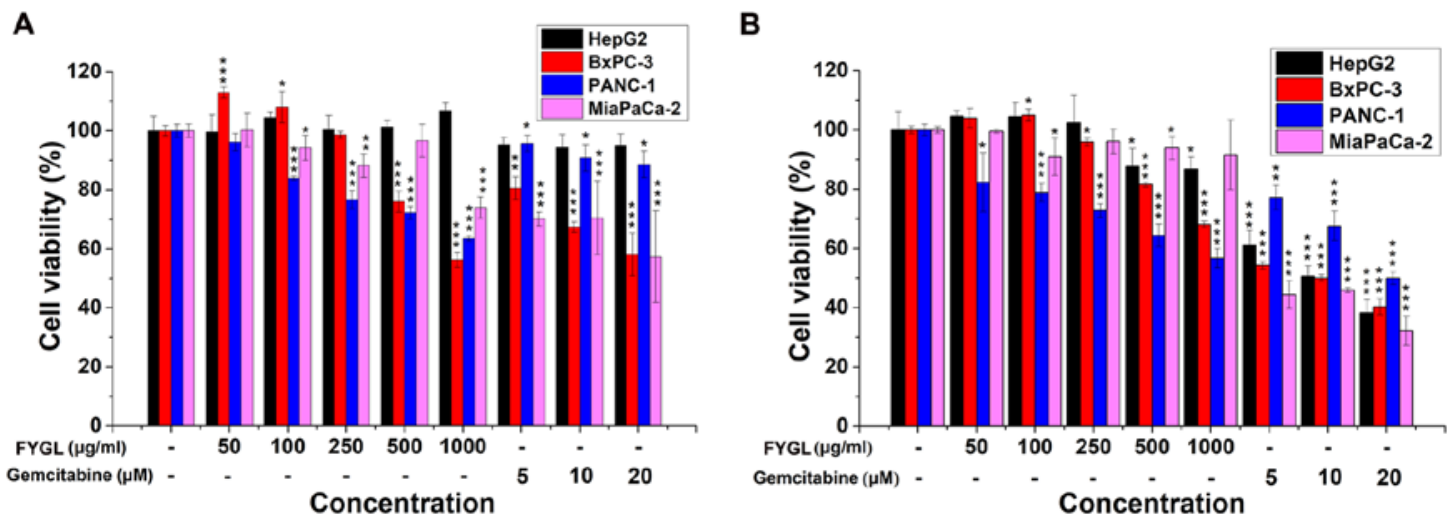

Figure 1. Cell viability were measured using a Cell Counting Kit-8 assay in 4 cell lines (PANC-1, BxPC-3, Mia PaCa-2 and HepG2) treated with 0-1,000 $\mu \mathrm{g} / \mathrm{ml}$ FYGL and 0-20 $\mu \mathrm{M}$ gemcitabine for (A) 24 and (B) $48 \mathrm{~h} .{ }^{*} \mathrm{P}<0.05 ;{ }^{* * *} \mathrm{P}<0.01 ;{ }^{* * *} \mathrm{P}<0.001$. FYGL, Fudan-Yueyang-Ganoderma lucidum.

of $5 \times 10^{5}$ cells/well. After incubation for $24 \mathrm{~h}$, the cells were treated with FYGL at a concentration range of $0-500 \mu \mathrm{g} / \mathrm{ml}$ for $24 \mathrm{~h}$. Following which, the cells were washed with PBS and added to $1 \mathrm{ml}$ serum-free medium with $10 \mu \mathrm{l}$ DCFH-DA per well. After incubation for $30 \mathrm{~min}$ at $37^{\circ} \mathrm{C}$, the level of ROS in the cells were identified using DCFH, and analyzed using flow cytometry (Beckman Coulter, Inc.), and the data were analyzed using FlowJo software (version 10.4; BD Biosciences).

Analysis of mitochondrial membrane potential. The cells were seeded in cell culture dishes at $37^{\circ} \mathrm{C}$ in a humidified atmosphere with $5 \% \mathrm{CO}_{2}$, at a density of $1 \times 10^{5}$ cells/well and incubated for $24 \mathrm{~h}$, then, the cells were treated with FYGL at a concentration range of $0-1,000 \mu \mathrm{g} / \mathrm{ml}$ for $24 \mathrm{~h}$. The medium was removed and the cells were washed with PBS, then stained with $10 \mu 1$ rhodamine 123 (Rh-123; a green fluorescent agent; $5 \mathrm{mg} / \mathrm{ml}$; Shanghai Yeasen Biotech Co. Ltd.) for $30 \mathrm{~min}$ in the dark at $37^{\circ} \mathrm{C}$, to detect the mitochondrial membrane potential. Following which, the cells were fixed with 4\% PFA for $10 \mathrm{~min}$ at $37^{\circ} \mathrm{C}$, and permeabilized with $0.3 \%$ Triton X-100. Subsequently, the cell nucleus and cytoskeleton were stained blue with DAPI and red with rhodamine-labeled phalloidin for $10 \mathrm{~min}$ at $37^{\circ} \mathrm{C}$, respectively. Images were taken by LSCM (magnification, x60; Nikon $\mathrm{C} 2+$, Nikon Corporation).

Detection of autophagy. The cells were seeded in cell culture dishes at $37^{\circ} \mathrm{C}$ in a humidified atmosphere with $5 \% \mathrm{CO}_{2}$, at a density of $1 \times 10^{5}$ cells/well then, treated with FYGL at a concentration range of $0-1,000 \mu \mathrm{g} / \mathrm{ml}$ for $24 \mathrm{~h}$. After washing with PBS three times, the cells were incubated with a Cyto-ID autophagy detection kit (Enzo Life Sciences, Inc.) for $30 \mathrm{~min}$ at $37^{\circ} \mathrm{C}$, which including a mitochondrial staining reagent Cyto-ID and nuclear staining reagent Hoechst 33258, subsequently were washed with PBS and fixed with $4 \%$ PFA for $15 \mathrm{~min}$ at $37^{\circ} \mathrm{C}$. Images were obtained using LSCM (magnification, x60; Nikon C2+; Nikon Corporation).

Western blot analysis. Total protein was lysed from the cells using a RIPA containing phenylmethylsulfonyl fluoride, then the concentration was measured using a BCA protein assay kit (all from Shanghai Yeasen Biotech Co.,Ltd.). Following which, the lysed proteins were separated using a 10-15\% SDS-PAGE and transferred to PVDF membranes (Beyotime Institute of Biotechnology). The membranes were blocked with a buffer containing $10 \mathrm{mM}$ Tris- $\mathrm{HCl},(\mathrm{pH} 7.4), 150 \mathrm{mM} \mathrm{NaCl}$, $0.1 \%$ Tween-20, and 5\% skimmed milk (Beyotime Institute of Biotechnology), then incubated with the primary antibodies for $12 \mathrm{~h}$ at $4^{\circ} \mathrm{C}$, followed by incubation with the HRP-conjugated secondary antibody for $1 \mathrm{~h}$ at $25^{\circ} \mathrm{C}$. The antibodies were detected using a super enhanced chemiluminescence detection reagent (Shanghai Yeasen Biotech Co., Ltd.) and a chemiluminescent imaging system (Bio-Rad ChemiDoc MP; Bio-Rad Laboratories, Inc.). GAPDH and $\beta$-actin were used as the loading controls.

Imaging mCherry-green fluorescent protein-LC $3 B$ (mCherry-GFP-LC3) fusion protein. The adenovirus expressing (Ad)-mCherry-GFP-LC3 fusion protein (Beyotime Institute of Biotechnology) was used to investigate the binding of autophagosomes and lysosomes. The PANC-1 cell line was transfected with ad-mCherry-GFP-LC3 adenovirus, at 20 multiplicity of infection for $24 \mathrm{~h}$ at $37^{\circ} \mathrm{C}$. Then, the culture medium was removed and fresh DMEM with FYGL at a concentration range of $0-500 \mu \mathrm{g} / \mathrm{ml}$ was added. After $24 \mathrm{~h}$, the cells were detected with LSCM (magnification, x60; Nikon $\mathrm{C} 2+$; Nikon Corporation).

Statistical analysis. The results are presented as the mean \pm standard deviation $(n=3)$. SPSS software (v20.0; IBM Corp.) was used for statistical analyses. ImageJ software (v1.51j8; National Institutes of Health) was used for digital analysis of the western blots. One-way ANOVA was performed to compare the mean values among multiple groups followed by Tukey's post hoc test. $\mathrm{P}<0.05$ was considered to indicate a statistically significant difference.

\section{Results}

Inhibition of pancreatic cancer cell viability by FYGL. To investigate the effects of FYGL on the viability of 2 different cancer cell lines, three pancreatic cancer cell lines, PANC-1, BxPC-3, and Mia PaCa-2, and one hepatic cell line, HepG2, were treated with FYGL, at a concentration range of $50-1,000 \mu \mathrm{g} / \mathrm{ml}$, with gemcitabine, as a positive control, at a concentration range of $5-20 \mu \mathrm{M}$. All the cell lines were treated for 24 (Fig. 1A) and $48 \mathrm{~h}$ (Fig. 1B), then the viability was 


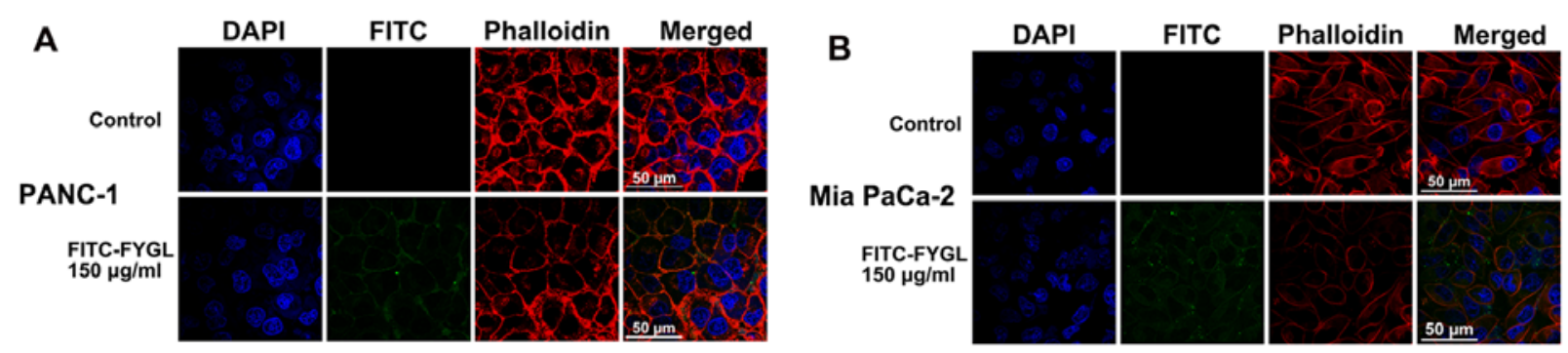

Figure 2. Fluorescence images of the (A) PANC-1 and (B) Mia PaCa-2 cell lines treated with or without FYGL. The green, blue and red channels indicate FITC-labeled FYGL, DAPI-stained cell nucleus, and rhodamine-labeled phalloidin-stained cytoskeleton, respectively. FYGL, Fudan-Yueyang-Ganoderma lucidum; DAPI, 4',6-diamidino-2-phenylindole; FITC, fluorescein isothiocyanate.

A

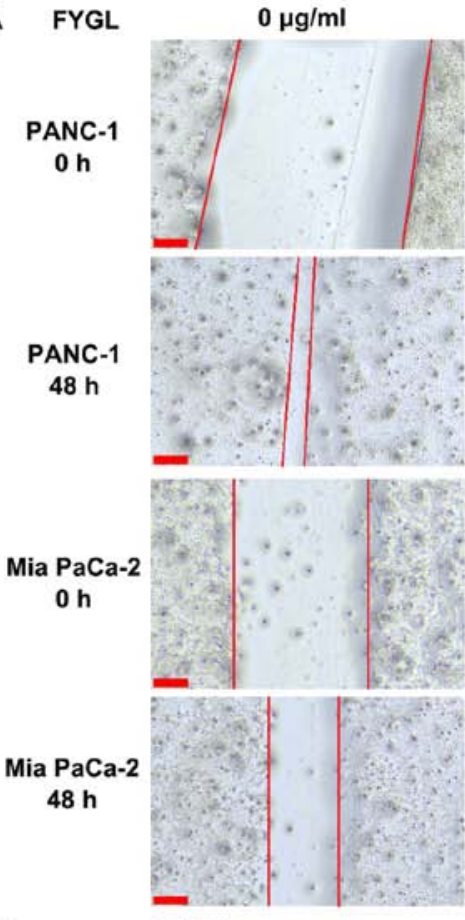

B

PANC-1

D

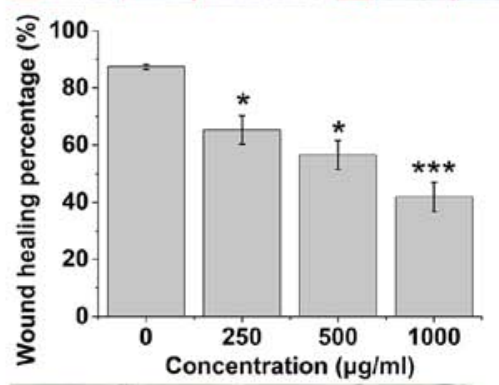

\section{PANC-1}

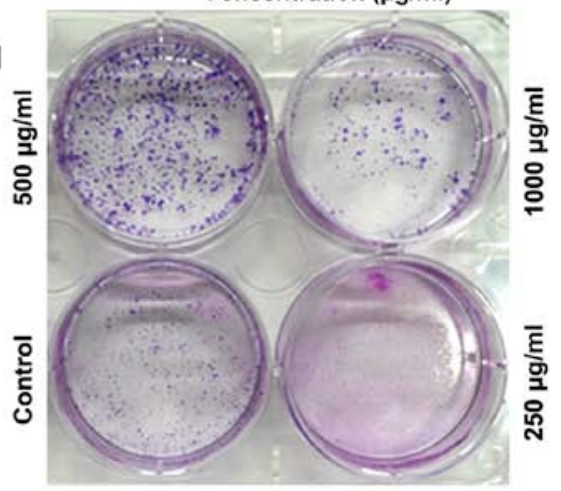

$250 \mu \mathrm{g} / \mathrm{ml}$
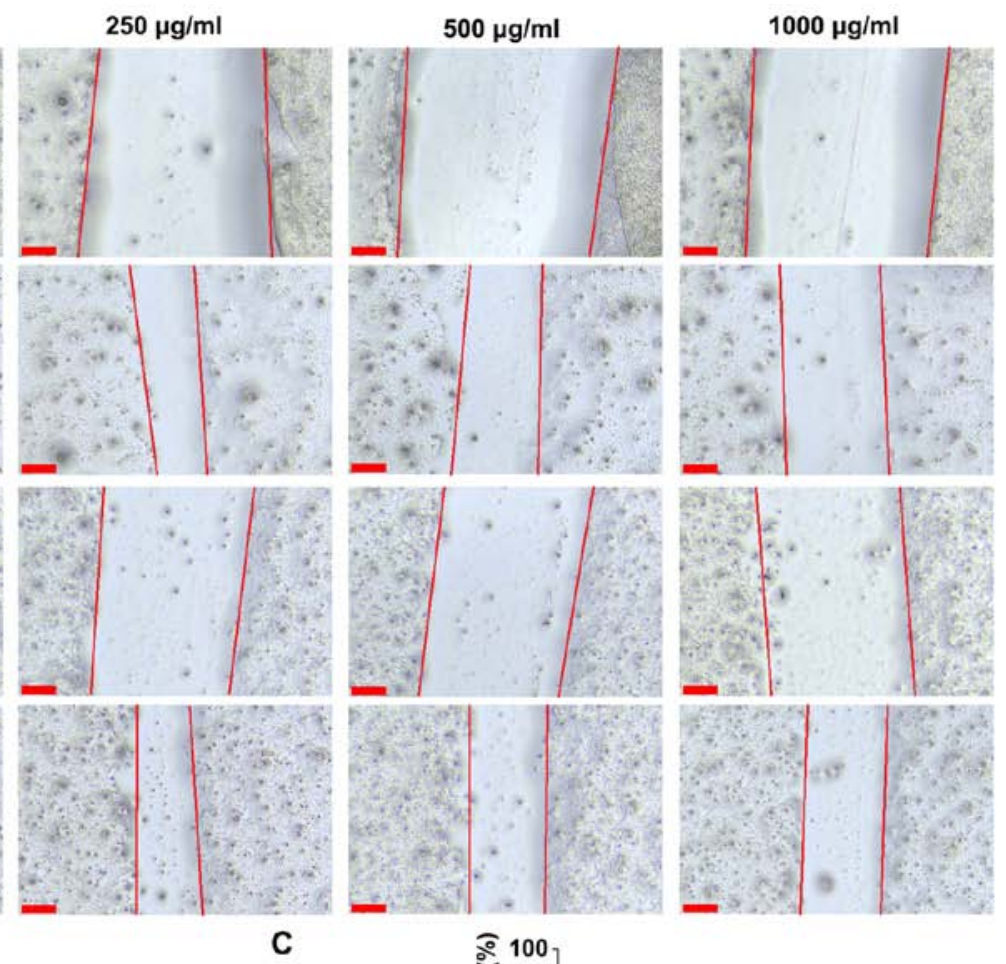

Mia PaCa-2

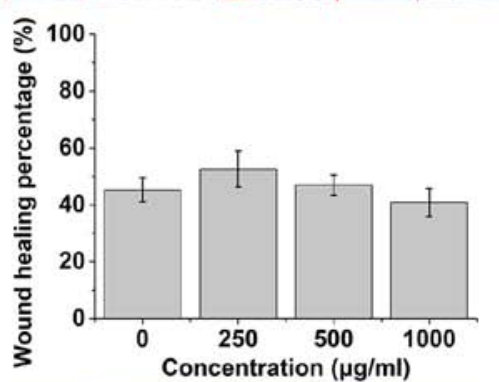

E

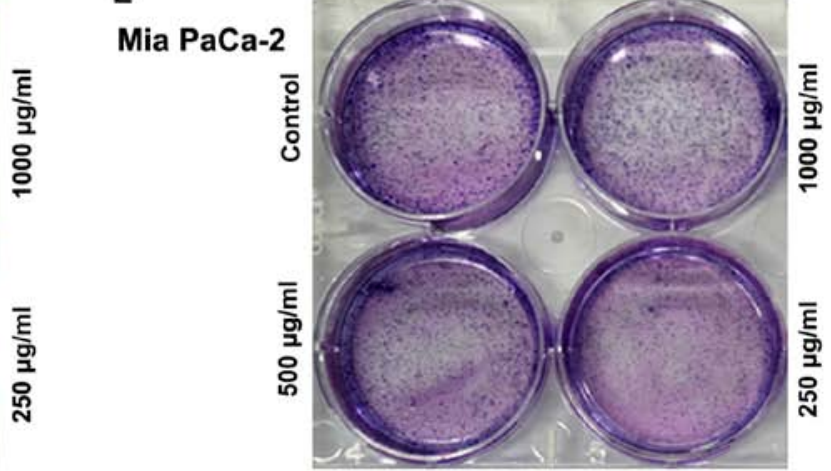

Figure 3. (A) Wound healing assay of the PANC-1 and Mia PaCa-2 cell lines treated with 0-1,000 $\mu \mathrm{g} / \mathrm{ml} \mathrm{FYGL} \mathrm{for} 0$ and $48 \mathrm{~h}$. Images were obtained at a magnification of $\mathrm{x} 4$. Scale bar, $200 \mu \mathrm{m}$. Statistical analysis for wound healing percentage on (B) PANC-1 cells and (C) Mia PaCa-2 cells treated with 0-1,000 $\mu \mathrm{g} / \mathrm{ml}$ FYGL. ${ }^{*} \mathrm{P}<0.05$; ${ }^{* * * *} \mathrm{P}<0.001$. Colony formation assay of (D) PANC-1 and (E) Mia PaCa-2 cells treated with $0-1,000 \mu \mathrm{g} / \mathrm{ml} \mathrm{FYGL.} \mathrm{The} \mathrm{cell} \mathrm{colonies} \mathrm{were} \mathrm{stained}$ using Giemsa. FYGL, Fudan-Yueyang-Ganoderma lucidum. 
A PANC-1

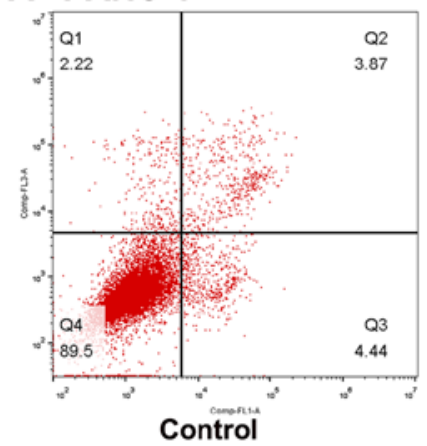

B Mia PaCa-2

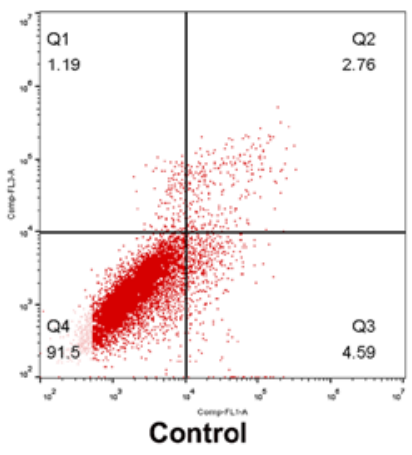

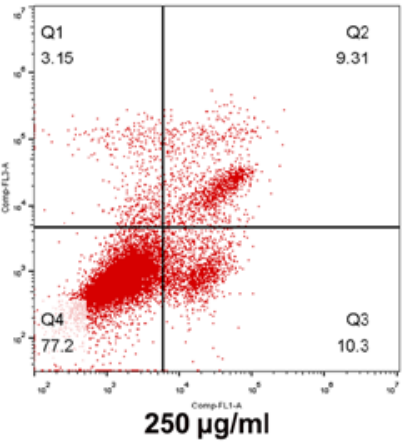

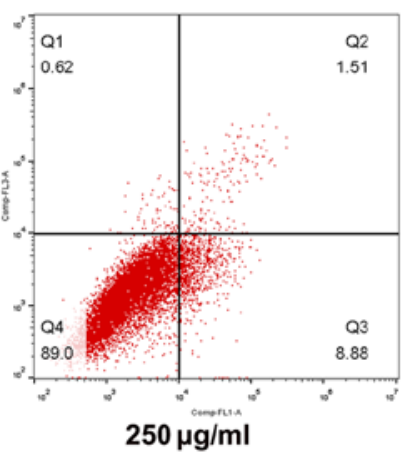

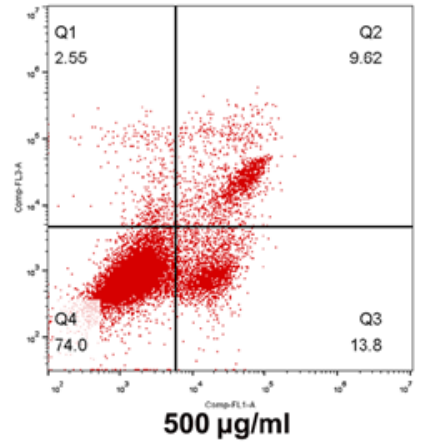
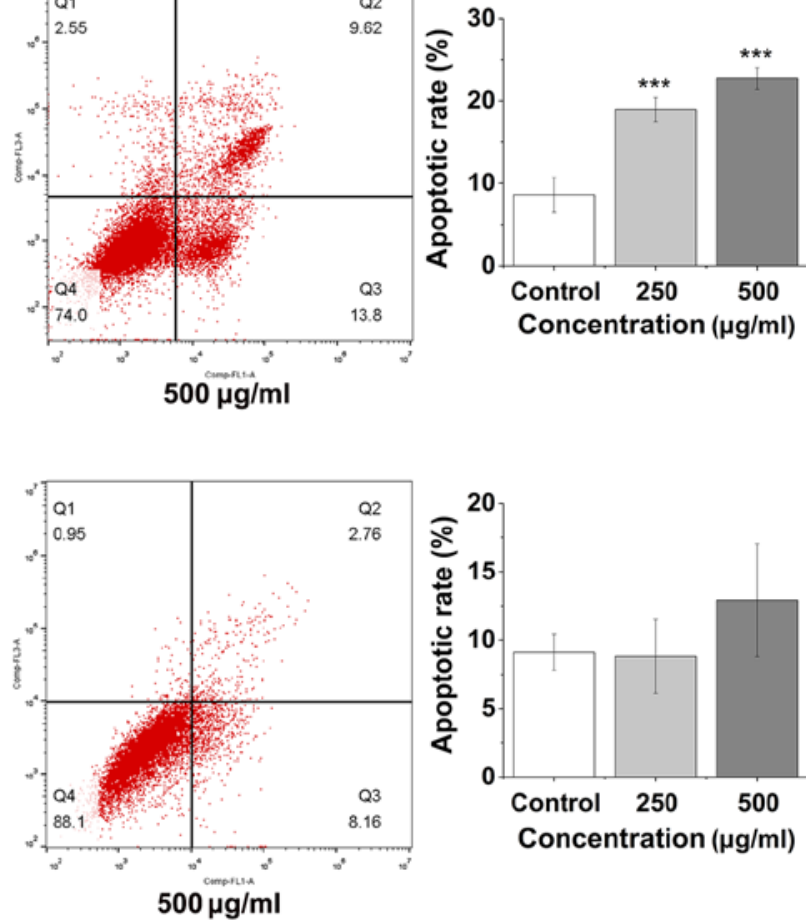

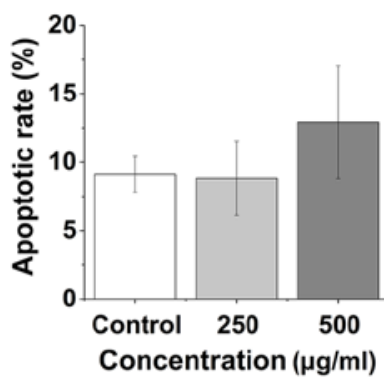

Figure 4. The apoptotic rates of (A) PANC-1 and (B) Mia PaCa-2 cells, treated with Fudan-Yueyang-Ganoderma lucidum, at different concentrations, were detected using flow cytometry. ${ }^{* * *} \mathrm{P}<0.001$.

investigated using a CCK-8 assay. The results indicated that FYGL had different effects on cell viability in the 2 different cancer cell lines. The viability of PANC- 1 and BxPC- 3 cells was markedly decreased by the treatment of FYGL in a dose dependent manner at both 24 and $48 \mathrm{~h}$, comparable with the cells treated with the positive agent, gemcitabine. The viability of the Mia PaCa-2 cells was not affected by FYGL treatment in a dose dependent manner, both at 24 and $48 \mathrm{~h}$. As well as in HepG2 cells, however, gemcitabine was markedly toxic for all the cell lines following treatment for $48 \mathrm{~h}$. The results, therefore, indicated that FYGL was moderate, safe, and selective for the given cell lines.

FYGL absorption in cells. To understand the functional mechanism of FYGL in the cells, the PANC- 1 and Mia PaCa- 2 cell lines were selected for further research. First, the absorption of FYGL into the cells was investigated. The FYGL, cell nucleus, and cytoskeleton were all labeled with fluorescent agents namely: FITC (green), DAPI (blue), and rhodamine-labeled phalloidin (red). As shown in Fig. 2, the green fluorescence from FYGL overlapped with the red fluorescence from the cytoskeleton. Furthermore, some green fluorescent areas were found between the red and the blue fluorescent areas (from the nucleus labelled with DAPI), indicating that FYGL was encapsulated by vesicles and dispersed into the cytoplasm. Some green fluorescent areas were found to be outside of the cells, indicating not all of the FYGL was absorbed into the cells; however, most of the FYGL was absorbed in the cells.

Effects of FYGL on cell migration and colony formation. Cell migration in cell treated with $F Y G L$ was determined using a wound healing assay. Both PANC-1 and Mia PaCa-2 cells were treated with $F Y G L$ for $48 \mathrm{~h}$. The cell migration of PANC-1 cells into the wound area was halted by the increased concentrations of FYGL (Fig. 3A). The wound healing percentage of PANC-1 cells significantly decreased at 250,500 and $1,000 \mu \mathrm{g} / \mathrm{ml}$ concentrations of FYGL compared with that in the control group (Fig. 3B). However, the wound healing percentage of Mia PaCa-2 cells increased at $250 \mu \mathrm{g} / \mathrm{ml}$ concentrations of FYGL and decreased at $1,000 \mu \mathrm{g} / \mathrm{ml}$ concentrations of FYGL, but no significant differences were observed compared with that in the control group, which indicated that cell migration was not affected by FYGL in the Mia PaCa-2 cells (Fig. 3C).

Fig. 3D and E showed the colony formation of the PANC-1 and $\mathrm{Mia} \mathrm{PaCa}-2$ cells treated with different concentrations of FYGL. A total of 200 cells, in each well, were incubated with FYGL for 12 days. The colony formation of the PANC-1 cells was low at higher concentrations, indicating sensitivity to FYGL treatment, while there was a high number of colonies with the Mia PaCa-2 cell line indicating insensitivity to FYGL treatment.

Effects of FYGL on apoptosis of the pancreatic cancer cells. Apoptosis of cancer cells is a critical index for an anticancer drug (23), and is typically investigated using an Annexin V-FITC/PI kit and measured using flow cytometry (24). The apoptotic rate of the PANC- 1 cells increased to $23 \%$, as the concentration of FYGL increased to $500 \mu \mathrm{g} / \mathrm{ml}$ (Fig. 4A), however, the apoptotic rate of Mia PaCa-2 cells was unaffected (Fig. 4B).

Furthermore, western blot analysis was used to analyze the expression levels of key proteins for example, caspase-3, Bcl-2 


\section{A PANC-1}

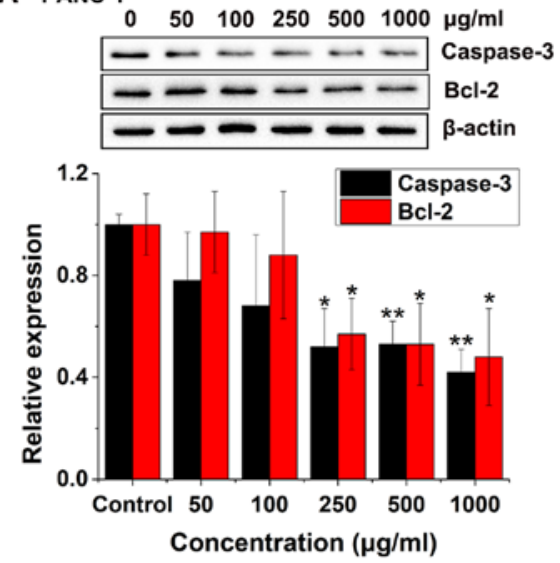

C Mia PaCa-2

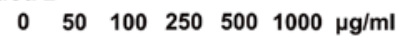
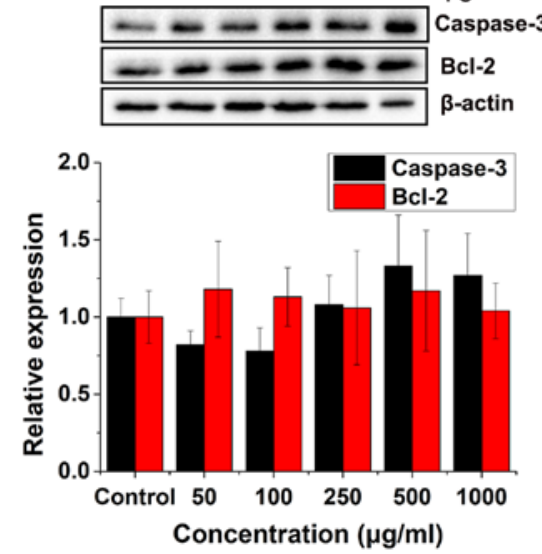

B PANC-1

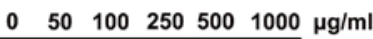
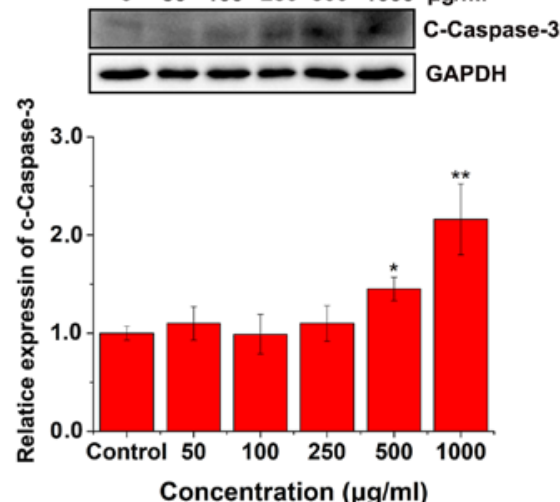

D Mia PaCa-2
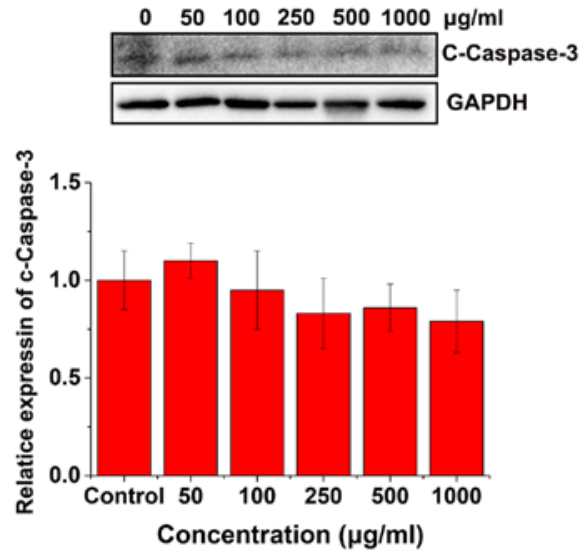

Figure 5. The relative protein expression levels of caspase-3 and Bcl-2 in (A) PANC-1 cells and in (C) Mia PaCa-2 cells treated with 0-1,000 $\mu$ g/ml FYGL and the relative protein expression levels of C-caspase-3 in (B) PANC-1 cells and in (D) Mia PaCa-2 cells treated with 0-1,000 $\mu \mathrm{g} / \mathrm{ml}$ FYGL, were analyzed using western blot analysis. $\beta$-actin and GAPDH are reference proteins. ${ }^{*} \mathrm{P}<0.05 ;{ }^{* *} \mathrm{P}<0.01$. FYGL, Fudan-Yueyang-Ganoderma lucidum; $\mathrm{C}$, cleaved.

and cleaved-caspase-3, which are involved in apoptosis. The production of cleaved caspase- 3 from caspase- 3 promotes cell apoptosis, while the expression level of Bcl-2 prevents the cells from undergoing apoptosis $(25,26)$. Fig. 5A shows that the protein expression levels of caspase- 3 and Bcl-2 in the PANC-1 cells significantly decreased at 250, 500 and $1,000 \mu \mathrm{g} / \mathrm{ml}$ concentrations of FYGL compared with that in the control group, while Fig. 5B shows that the protein expression level of cleaved-caspase- 3 in the PANC-1 cells was significantly increased, at 500 and $1,000 \mu \mathrm{g} / \mathrm{ml}$ concentrations of FYGL, compared with that in the control group. The results indicated that cell apoptosis in the PANC-1 cells was induced by FYGL.

However, Fig. 5C and D demonstrated that the protein expression levels of caspase- 3 in the Mia PaCa-2 cells decreased at 50 and $100 \mu \mathrm{g} / \mathrm{ml}$ concentrations of FYGL and increased at 500 and $1,000 \mu \mathrm{g} / \mathrm{ml}$ concentrations of FYGL, but no significant differences were observed compared with that in the control group. The protein expression levels of Bcl-2 in the Mia PaCa-2 cells increased at 50, 100 and $500 \mu \mathrm{g} / \mathrm{ml}$ concentrations of FYGL, but no significant differences were observed compared with that in the control group. The protein expression levels of cleaved-caspase- 3 in the Mia PaCa- 2 cells increased at $50 \mu \mathrm{g} / \mathrm{ml}$ concentrations of FYGL and decreased at 250,500 and $1,000 \mu \mathrm{g} / \mathrm{ml}$ concentrations of FYGL, but no significant differences were observed compared with that in the control group. These results indicated that FYGL does not induce Mia PaCa-2 cell apoptosis.

FYGL effects on oxidative stress and MMP. The fluorescent probe, DCFH-DA was used to detect ROS in the cells using flow cytometry. Fig. 6A showed that the ROS level in the PANC-1 cells significantly increased as the concentration of FYGL increased from 0 to $500 \mu \mathrm{g} / \mathrm{ml}$; however, there was no increase in the Mia PaCa-2 cells (Fig. 6B). The decrease of MMP has been associated with the increase of ROS, and with cell apoptosis $(11,27)$.

Therefore, in the subsequent experiments, the green fluorescent agent, Rh-123 was used to detect the MMP in the PANC-1 and Mia PaCa-2 cell lines, treated with FYGL for $24 \mathrm{~h}$ and analyzed using confocal microscopy. Fig. 7A and B showed the fluorescent images of the PANC-1 and Mia PaCa-2 cell lines, respectively; wherein blue, green, and red represent the cell nucleus (DAPI), MMP (Rh-23), and cytoskeleton (rhodamine-labeled phalloidin), respectively. The MMP was found to be deceased in the PANC-1 cells, as the concentrations of FYGL increased; however, there was no marked change in the Mia PaCa- 2 cells, which were consistent with the results from the ROS experiments. The results indicated that FYGL could selectively induce the production of ROS, leading to the reduction of the MMP and apoptosis in the PANC-1 cells line. 
A PANC-1
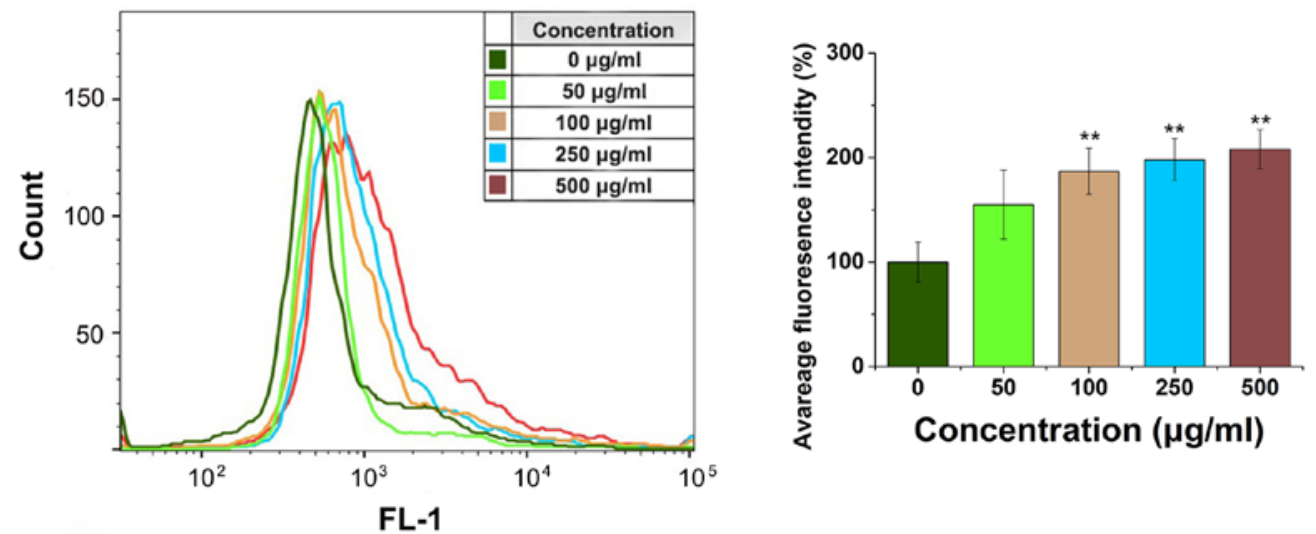

B $\quad$ Mia PaCa-2
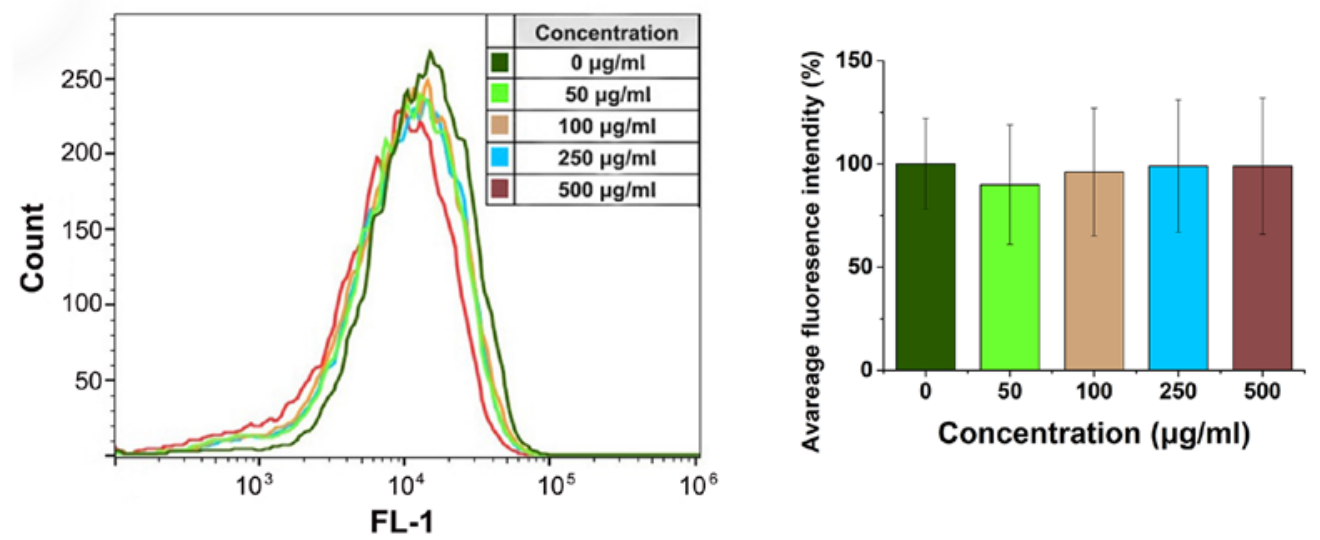

Figure 6. ROS production in (A) PANC-1 and (B) Mia PaCa-2 cells, treated with Fudan-Yueyang-Ganoderma lucidum at different concentrations, was detected using flow cytometry and a DCFH-DA fluorescent probe. ${ }^{* *} \mathrm{P}<0.01$.

A PANC-1

FYGL $\quad 0 \mu \mathrm{g} / \mathrm{ml} \quad 250 \mu \mathrm{g} / \mathrm{ml} 500 \mu \mathrm{g} / \mathrm{ml} 1000 \mu \mathrm{g} / \mathrm{ml}$

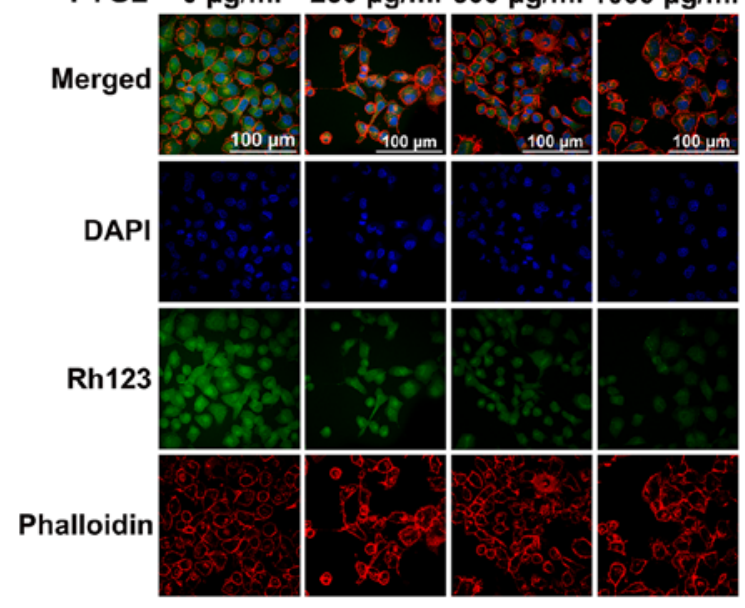

B Mia PaCa-2

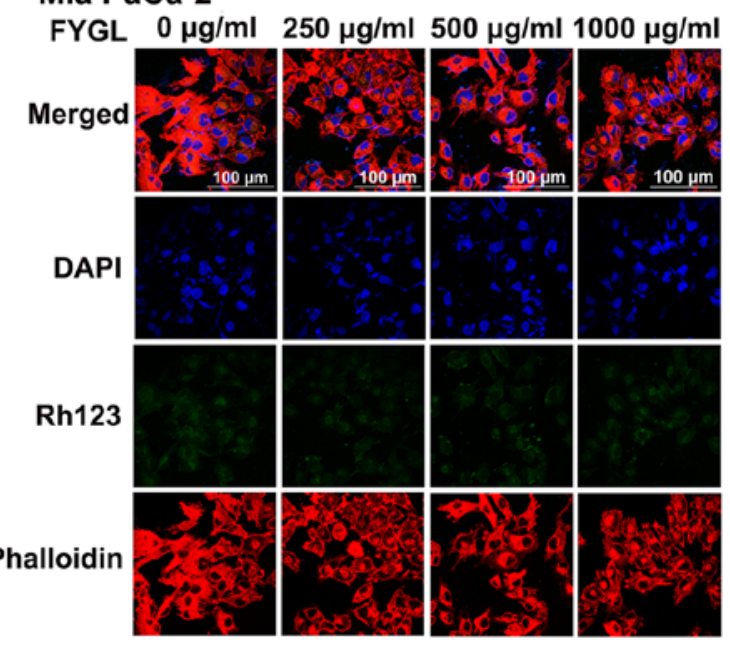

Figure 7. The mitochondrial membrane potential of (A) PANC-1 and (B) Mia PaCa-2 cells, treated with 0-1,000 $\mu \mathrm{g} / \mathrm{ml}$ FYGL, was detected using Rh-123 probe. Rh-123, rhodamine 123; FYGL, Fudan-Yueyang-Ganoderma lucidum; DAPI, 4',6-diamidino-2-phenylindole.

Effects of FYGL on autophagy of the pancreatic cancer cells. The cell autophagy process occurs from autophagosome formation, along with organelle damage, to the movement of autophagosomes into lysosomes for the recycling of damaged organelles (18). The polyubiquitinated protein, LC3-I/II, and the polyubiquitin-binding protein, $\mathrm{P} 62$, are autophagic effector proteins. During the cell autophagy process, LC3-I is covalently bound to phosphatidylethanolamine (PE) to form LC3-II, which then localizes on the autophagosome membrane (28). Once the autophagy process has been completed, the P62 protein is degraded, and the autophagosomes enter the lysosomes (29). Fig. 8A showed that the autophagosomes, labeled with the green fluorescent agent, cyto-ID, increased, as the concentration of FYGL increased, in the PANC-1 cells 

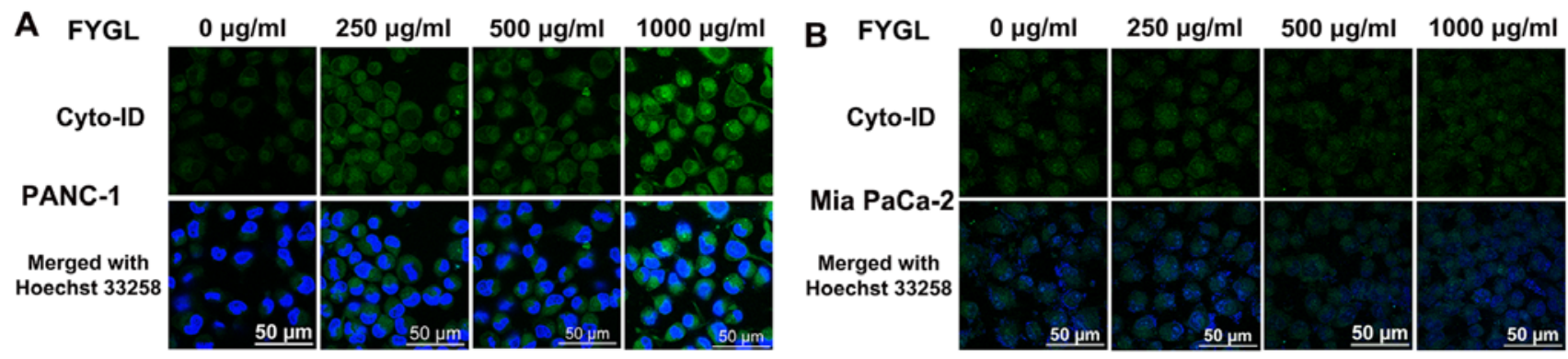

Figure 8. The cyto-ID stained autophagosomes and the Hoechst 33258 stained cell nucleus in (A) PANC-1 and (B) Mia PaCa-2 cells, treated with 0-1,000 $\mu \mathrm{g} / \mathrm{ml} \mathrm{FYGL}$ for $24 \mathrm{~h}$, were analyzed using confocal microscopy. FYGL, Fudan-Yueyang-Ganoderma lucidum.

A PANC-1

$0 \quad 501002505001000 \mu \mathrm{g} / \mathrm{ml}$
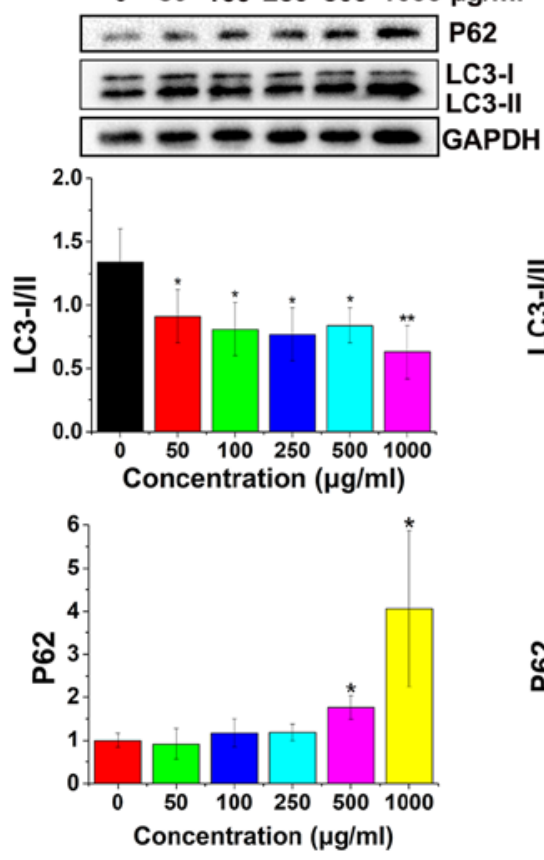

B Mia PaCa-2

$0 \quad 501002505001000 \mu \mathrm{g} / \mathrm{ml}$
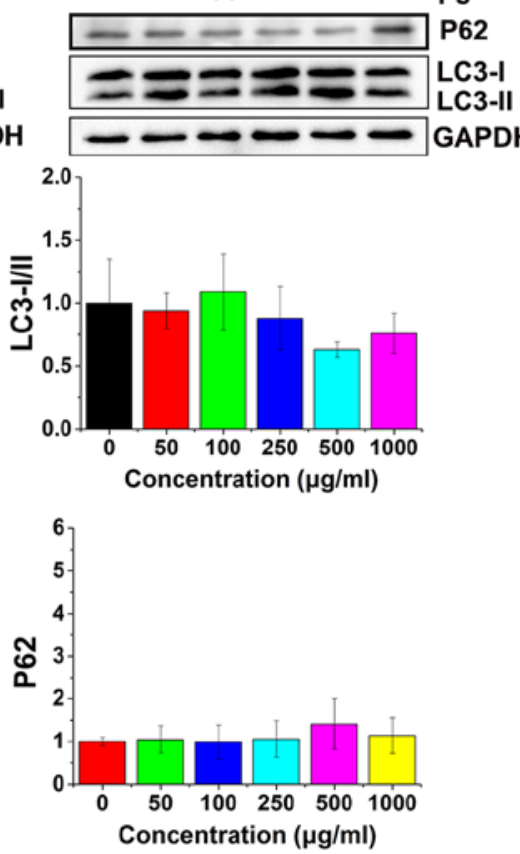

C PANC-1

FYGL $\quad 0 \mu \mathrm{g} / \mathrm{ml}$ $500 \mu \mathrm{g} / \mathrm{ml}$
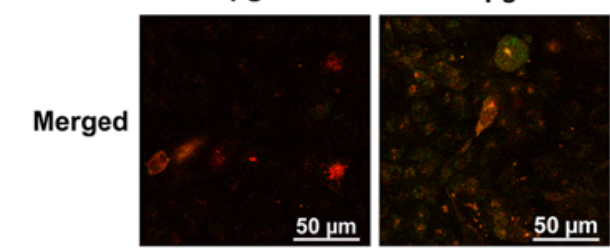

mCherry
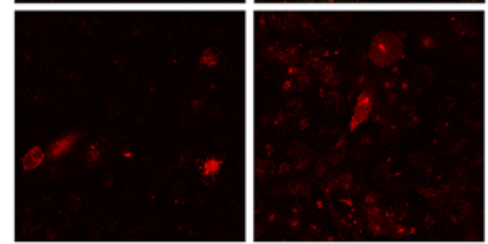

GFP
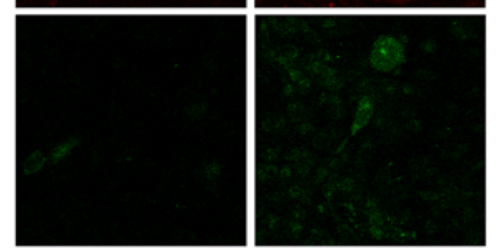

Figure 9. The relative protein expression levels of P62, LC3-I and LC3-II in (A) PANC-1 and (B) Mia PaCa-2 cells, treated with 0-1,000 $\mu$ g/ml FYGL, were analyzed using western blot analysis. (C) The fluorescence images of the PANC-1 cells infected with Ad-mCherry-GFP-LC3 adenovirus and treated with FYGL for 24 h. ${ }^{*} \mathrm{P}<0.05 ;{ }^{* *} \mathrm{P}<0.01$. FYGL, Fudan-Yueyang-Ganoderma lucidum; GFP, green fluorescent protein; Ad, adenovirus.

treated with FYGL for 24 h, suggesting that FYGL promoted autophagosome formation in the PANC-1 cell line. FYGL had almost no effect on the fluorescence intensity in the Mia PaCa-2 cell line, indicating that FYGL did not induce autophagosome formation in the Mia PaCa-2 cell line (Fig. 8B).

Fig. 9A and $\mathrm{B}$ showed the protein expression level of LC3-I/II and P62 in the PANC-1 and Mia PaCa-2 cells, respectively, treated with different concentrations of FYGL for $24 \mathrm{~h}$. In the PANC-1 cells, the cascade protein ratio of LC3-I/II significantly decreased at 50, 100, 250, 500 and $1,000 \mu \mathrm{g} / \mathrm{ml}$ concentrations of FYGL compared with that in the control group further indicating that there was an increase in the number of autophagosomes in the PANC-1 cells. However, it was found that in the PANC-1 cells treated with different concentrations of FYGL, the relative protein expression level of P62 was significantly increased, at 500 and $1,000 \mu \mathrm{g} / \mathrm{ml}$ compared with that in the control group, indicating that the cell autophagy process was halted, and not completed in the signaling pathway. In the Mia $\mathrm{PaCa}-2$ cell line, the ratio of LC3-I/II decreased at 50, 250, 500 and $1,000 \mu \mathrm{g} / \mathrm{ml}$ concentrations of FYGL and increased at $100 \mu \mathrm{g} / \mathrm{ml}$ concentrations of FYGL, but no significant differences were observed compared with that in the control group. The protein expression levels of P62 in the Mia PaCa-2 cells increased at 500 and $1,000 \mu \mathrm{g} / \mathrm{ml}$ concentrations of FYGL, but no significant differences were observed compared with that in the control group. These results indicated that FYGL had almost no effect on the autophagy of Mia PaCa-2 cells.

In addition, the fluorescent adenovirus, admCherry-GFP-LC3 was used to confirm that the autophagosomes enter the lysosomes. When the ad-mCherry-GFP-LC3 adenovirus, bound to the autophagosomes, are present in the lysosomes of cells, the GFP in the fusion protein is quenched. Fig. 9C shows the fluorescence images of the PANC-1 cells infected with Ad-mCherry-GFP-LC3 and treated with $(500 \mu \mathrm{g} / \mathrm{ml})$ or without (control) FYGL for $24 \mathrm{~h}$. It was 


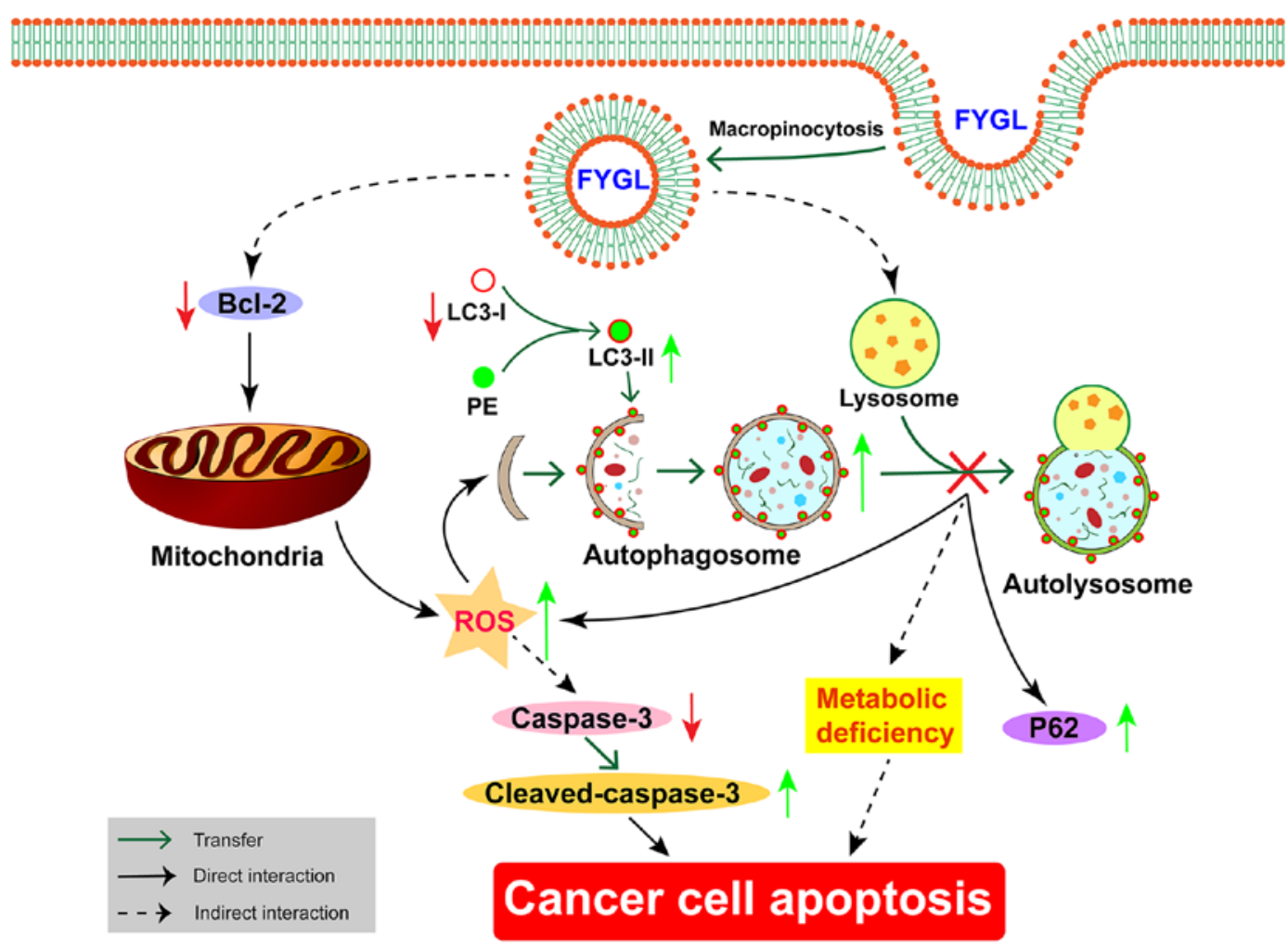

Figure 10. The proposed mechanism of FYGL killing the PANC-1 cancer cells. FYGL inhibits Bcl-2 protein expression and, selectively, induces the increase in ROS, leading to the decrease of caspase-3/cleaved-caspase-3, and simultaneously halts the downstream process of autophagy by inhibiting the fusion of autophagosomes to lysosomes, leading to cell metabolic deficiency. Both processes result in cancer cell apoptosis. Green arrow, increase; red arrow, decrease; FYGL, Fudan-Yueyang-Ganoderma lucidum; PE, phosphatidylethanolamine; ROS, reactive oxygen species.

found that the fluorescent intensity of GFP in FYGL-treated cells was markedly higher compared with that in the control cells, suggesting that FYGL prevented autophagosomes from entering the lysosomes.

\section{Discussion}

The present study demonstrated that FYGL could promote cell apoptosis in the PANC-1 cell line, but not in the Mia PaCa-2 cell line. The Bcl-2 protein is one of the most important anti-apoptotic proteins, and prevents the loss of MMP (26). ROS can damage lipids, proteins, DNA, and organelles, leading to cell apoptosis (12). Numerous studies (30-34) have found that drugs, such as Berberine, BML-275 and Resveratrol could induce apoptosis of the PANC-1 and MiaPaCa- 2 cell lines via ROS production, without selectivity, indicating that ROS has the same sensitivity for both the PANC-1 and Mia PaCa- 2 cell lines treated with those drugs; therefore, we hypothesized that a similar mechanism was involved following treatment with FYGL. Western blot analysis showed that the protein expression level of the Bcl-2 protein was decreased in the PANC-1 cell line treated with FYGL. In addition, the ROS was also increased, as a result, the caspase-3/cleaved-caspase-3 proteins were activated, which led to a reduction in MMP and ultimately, PANC-1 cell apoptosis; however, this did not occur in the Mia PaCa-2 cell line.

Furthermore, ROS also plays a crucial role in the activation of cell autophagy $(18,35)$. Cell autophagy can provide nutrients and energy for cancer cells, promote the development of cancer cells, and leads to cancer cell resistance to treatment. The excessive accumulation of ROS can induce cell autophagy (36). In the present study, the ratio of LC3-I/II was decreased in PANC-1 cells, indicating an increase in the number of autophagosomes. However, the protein expression level of P62 was increased in the PANC-1 cells treated with 500 and $1,000 \mu \mathrm{g} / \mathrm{ml}$ FYGL compared with that in the control cells, indicating an inhibition of autophagy. We hypothesized that the failure of the autophagy process resulted from the inhibition of autophagosomes from entering the lysosomes. A schematic of FYGL killing pancreatic cancer cells was proposed, as shown in Fig. 10. First, FYGL was absorbed into the cells probably through the process of micropinocytosis (37). Then, FYGL decreased MMP and induced ROS production through inhibiting the expression of $\mathrm{Bcl}-2$ protein. The increase of ROS production damaged organelles and proteins, which activated both the cell autophagy and cell apoptosis pathways. More autophagosomes were synthesized to wrap damaged organelles, consuming lots of LC3-I protein and PE to synthesize LC3-II protein, which is an important part of the autophagosome membrane. However, FYGL halts the downstream process of autophagy by inhibiting the fusion of autophagosomes and lysosomes, which caused the upregulation of P62 proteins and increased the production of ROS, as well as induced metabolic deficiency. The increase of ROS and the blockage of autophagy promoted apoptosis in the PANC-1 cells in the present study.

In addition, Boya et al (22) reported that autophagy inhibition lead to the accumulation of defective mitochondria and an 
increase in ROS production, while Humpton et al (38) found that KRAS-NIX-mediated mitophagy was a novel driver of glycolysis and redox activities. Future studies will investigate whether the energy metabolic processes of pancreatic cancer cells are forced to switch under the treatment of FYGL.

In pancreatic cells, macropinocytosis drives the internalization of extracellular proteins and saccharides, and thereafter degradation in lysosomes, to produce amino acids and sugars $(39,40)$. When nutrients, such as amino acids, are plentiful, the mTORC1 signaling pathway could inactivate lysosomes to inhibit autophagy $(41,42)$. FYGL endocytosed in the PANC-1 cells might be degraded into amino acids and sugars, potentially inhibiting cell autophagy.

A limitation of the present study was that in vitro experiments alone are not sufficient to validate the inhibitory effects of FYGL on tumors. Therefore, future studies should include in vivo experiments. However, the present study conclusively demonstrated that, FYGL could selectively kill pancreatic cancer cells through regulation of ROS and the simultaneous inhibition of autophagy in the following processes: FYGL promoted PANC-1 cell apoptosis by inducing ROS, and the increase of ROS increased the number of autophagosomes. On the other hand, FYGL halts the downstream process of autophagy by inhibiting the fusion of autophagosomes and lysosomes. This increased the accumulation of defective mitochondria and the production of ROS, as well as induced metabolic deficiency. Both processes promoted apoptosis in the PANC-1 cells. The results from the present study suggested that FYGL could be used as a potential agent for the treatment of pancreatic cancer.

\section{Acknowledgements}

Not applicable.

\section{Funding}

The present study was supported by the Natural Science Foundation of China (grant nos. 21374022 and 81374032); The Scientific National Major Scientific and Technological Special Project for 'Significant New Drugs Development' (grant no. 2017ZX09301006) and the Shanghai Science and Technology Innovation Action Plan 'Science and Technology Support Project in Biomedical Science' (grant no. 17401902700).

\section{Availability of data and materials}

The datasets used and/or analyzed during the current study are available from the corresponding author on reasonable request.

\section{Author's contributions}

$\mathrm{XW}$ and $\mathrm{PZ}$ designed and performed the experiments. $\mathrm{LJ}$ and JL performed part of the western blotting experiments. HL, YP and SY performed the experiments involving cell culture and cell viability. ZZ, YH, HY and YT contributed to the data analysis. XW wrote the manuscript. HY and PZ reviewed and revised the manuscript for important intellectual information. PZ conceived the study and was responsible for the revision of the manuscript and final decision to submit the article for publication. All authors read and approved the final manuscript.

\section{Ethics approval and consent to participate}

Not applicable.

\section{Patient consent for publication}

Not applicable.

\section{Competing interests}

The authors declare that they have no competing interests.

\section{References}

1. Siegel RL, Miller KD and Jemal A: Cancer statistics, 2019. CA Cancer J Clin 69: 7-34, 2019.

2. Kamisawa T, Wood LD, Itoi T and Takaori K: Pancreatic cancer. Lancet 388: 73-85, 2016.

3. Burris HR III, Moore MJ, Andersen J, Green MR, Rothenberg ML, Modiano MR, Cripps MC, Portenoy RK, Storniolo AM, Tarassoff P, et al: Improvements in survival and clinical benefit with gemcitabine as first-line therapy for patients with advanced pancreas cancer: A randomized trial. J Clin Oncol 15: 2403-2413, 1997.

4. Shiao MS: Natural products of the medicinal fungus Ganoderma lucidum: Occurrence, biological activities, and pharmacological functions. Chem Rec 3: 172-180, 2003.

5. Teng BS, Wang CD, Yang HJ, Wu JS, Zhang D, Zheng M, Fan ZH, Pan D and Zhou P: A protein tyrosine phosphatase 1B activity inhibitor from the fruiting bodies of Ganoderma lucidum (Fr.) Karst and its hypoglycemic potency on streptozotocin-induced type 2 diabetic mice. J Agric Food Chem 59: 6492-6500, 2011.

6. Pan D, Wang L, Chen C, Hu B and Zhou P: Isolation and characterization of a hyperbranched proteoglycan from Ganoderma lucidum for anti-diabetes. Carbohyd Polym 117: 106-114, 2015.

7. Pan D, Zhang D, Wu J, Chen C, Xu Z, Yang H and Zhou P: Antidiabetic, antihyperlipidemic and antioxidant activities of a novel proteoglycan from Ganoderma lucidum fruiting bodies on $\mathrm{db} / \mathrm{db}$ mice and the possible mechanism. PLoS One 8: e68332, 2013.

8. Teng BS, Wang CD, Zhang D, Wu JS, Pan D, Pan LF, Yang HJ and Zhou P: Hypoglycemic effect and mechanism of a proteoglycan from ganoderma lucidum on streptozotocin-induced type 2 diabetic rats. Eur Rev Med Pharmacol Sci 16: 166-175, 2012.

9. Gorrini C, Harris IS and Mak TW: Modulation of oxidative stress as an anticancer strategy. Nat Rev Drug Discov 12: 931-947, 2013.

10. Chen Y, McMillan-Ward E, Kong J, Israels SJ and Gibson SB: Oxidative stress induces autophagic cell death independent of apoptosis in transformed and cancer cells. Cell Death Differ 15: 171-182, 2008.

11. Khan M, Ding C, Rasul A, Yi F, Li T, Gao H, Gao R, Zhong L, Zhang K, Fang $\mathrm{X}$ and Ma T: Isoalantolactone induces reactive oxygen species mediated apoptosis in pancreatic carcinoma PANC-1 cells. Int J Biol Sci 8: 533-547, 2012.

12. Schumacker PT: Reactive oxygen species in cancer cells: Live by the sword, die by the sword. Cancer Cell 10: 175-176, 2006.

13. Li PF, Dietz R and von Harsdorf R: p53 regulates mitochondrial membrane potential through reactive oxygen species and induces cytochrome c-independent apoptosis blocked by Bcl-2. EMBO J 18: 6027-6036, 1999.

14. de Vries HE, Witte M, Hondius D, Rozemuller AJ, Drukarch B, Hoozemans $\mathbf{J}$ and van Horssen $\mathrm{J}$ : Nrf2-induced antioxidant protection: A promising target to counteract ROS-mediated damage in neurodegenerative disease? Free Radic Biol Med 45: 1375-1383, 2008.

15. Hur J, Sullivan KA, Schuyler AD, Hong Y, Pande M, States DJ, Jagadish HV and Feldman EL: Literature-based discovery of diabetes- and ROS-related targets. BMC Med Genomics 3: 49, 2010.

16. Pelicano H, Carney D and Huang P: ROS stress in cancer cells and therapeutic implications. Drug Resist Updat 7: 97-110, 2004. 
17. Liochev SI: Reactive oxygen species and the free radical theory of aging. Free Radic Biol Med 60: 1-4, 2013.

18. Mizushima N: Autophagy: Process and function. Genes Dev 21: 2861-2873, 2007.

19. Degenhardt K, Mathew R, Beaudoin B, Bray K, Anderson D, Chen G, Mukherjee C, Shi Y, Gélinas C, Fan Y, et al: Autophagy promotes tumor cell survival and restricts necrosis, inflammation, and tumorigenesis. Cancer Cell 10: 51-64, 2006.

20. Guo JY, Chen HY, Mathew R, Fan J, Strohecker AM, Karsli-Uzunbas G, Kamphorst JJ, Chen G, Lemons JM, Karantza V, et al: Activated Ras requires autophagy to maintain oxidative metabolism and tumorigenesis. Genes Dev 25 460-470, 2011.

21. Yang S, Wang X, Contino G, Liesa M, Sahin E, Ying H, Bause A, Li Y, Stommel JM, Dell'Antonio G, et al: Pancreatic cancers require autophagy for tumor growth. Genes Dev 25: 717-729, 2011.

22. Boya P, Gonzalez-Polo RA, Casares N, Perfettini JL, Dessen P, Larochette N, Metivier D, Meley D, Souquere S, Yoshimori $\mathrm{T}$, et al: Inhibition of macroautophagy triggers apoptosis. Mol Cell Biol 25: 1025-1040, 2005.

23. El-Khattouti A, Selimovic D, Haikel Y and Hassan M: Crosstalk between apoptosis and autophagy: Molecular mechanisms and therapeutic strategies in cancer. J Cell Death 6: 37-55, 2013.

24. Chen S, Cheng AC, Wang MS and Peng X: Detection of apoptosis induced by new type gosling viral enteritis virus in vitro through fluorescein annexin V-FITC/PI double labeling. World J Gastroenterol 14: 2174-2178, 2008.

25. Budihardjo I, Oliver H, Lutter M,Luo X and Wang X: Biochemical pathways of caspase activation during apoptosis. Annu Rev Cell Dev Biol 15: 269-290, 1999.

26. Yang J, Liu X, Bhalla K, Kim CN, Ibrado AM, Cai J, Peng TI, Jones DP and Wang X: Prevention of apoptosis by Bcl-2: Release of cytochrome c from mitochondria blocked. Science 275 1129-1132, 1997

27. Poupel F, Aghaei M, Movahedian A, Jafari SM and Shahrestanaki MK: Dihydroartemisinin induces apoptosis in human bladder cancer cell lines through reactive oxygen species, mitochondrial membrane potential, and cytochrome c pathway. Int J Prev Med 8: 78, 2017.

28. Kabeya Y, Mizushima N, Ueno T, Yamamoto A, Kirisako T, Noda T, Kominami E, Ohsumi Y and Yoshimori T: LC3, a mammalian homologue of yeast Apg8p, is localized in autophagosome membranes after processing. EMBO J 19: 5720-5728, 2000.

29. Pankiv S, Clausen TH, Lamark T, Brech A, Bruun JA, Outzen H, $\emptyset$ vervatn A, Bjørkøy G and Johansen T: p62/SQSTM1 binds directly to Atg8/LC3 to facilitate degradation of ubiquitinated protein aggregates by autophagy. J Biol Chem 282: 24131-24145, 2007.

30. Park SH, Sung JH, Kim EJ and Chung N: Berberine induces apoptosis via ROS generation in PANC-1 and MIA-PaCa2 pancreatic cell lines. Braz J Med Biol Res 48: 111-119, 2015.
31. Duong HQ, Hwang JS, Kim HJ, Seong YS and Bae I: BML-275, an AMPK inhibitor, induces DNA damage, G2/M arrest and apoptosis in human pancreatic cancer cells. Int $\mathbf{J}$ Oncol 41: 2227-2236, 2012.

32. Messner MC and Cabot MC: Cytotoxic responses to $\mathrm{N}$-(4-hydroxyphenyl)retinamide in human pancreatic cancer cells. Cancer Chemother Pharmacol 68: 477-487, 2011.

33. Vaquero EC, Edderkaoui M, Pandol SJ, Gukovsky I and Gukovskaya AS: Reactive oxygen species produced by NAD(P) $\mathrm{H}$ oxidase inhibit apoptosis in pancreatic cancer cells. J Biol Chem 279: 34643-34654, 2004.

34. Cheng L, Yan B, Chen K, Jiang Z, Zhou C, Cao J, Qian W, Li J, Sun L, Ma J, et al: Resveratrol-induced downregulation of NAF-1 enhances the sensitivity of pancreatic cancer cells to gemcitabine via the ROS/Nrf2 signaling pathways. Oxid Med Cell Longev 2018: 9482018, 2018.

35. Scherz-Shouval R, Shvets E, Fass E, Shorer H, Gil L and Elazar Z: Reactive oxygen species are essential for autophagy and specifically regulate the activity of Atg4. EMBO J 26: 1749-1760, 2007.

36. Scherz-Shouval R and Elazar Z: ROS, mitochondria and the regulation of autophagy. Trends Cell Biol 17: 422-427, 2007.

37. Yang Z, Wu F, Yang $\mathrm{H}$ and Zhou P: Endocytosis mechanism of a novel proteoglycan, extracted from Ganoderma lucidum, in HepG2 cells. Rsc Adv 7: 41779-41786, 2017.

38. Humpton TJ, Alagesan B, DeNicola GM, Lu D, Yordanov GN, Leonhardt CS, Yao MA, Alagesan P, Zaatari MN, Park Y, et al: Oncogenic KRAS induces NIX-mediated mitophagy to promote pancreatic cancer. Cancer Discov 9: 1268-1287, 2019.

39. Zhang Y and Commisso C: Macropinocytosis in cancer: A complex signaling network. Trends Cancer 5: 332-334, 2019.

40. Commisso C, Davidson SM, Soydaner-Azeloglu RG, Parker SJ, Kamphorst JJ, Hackett S, Grabocka E, Nofal M, Drebin JA, Thompson CB, et al: Macropinocytosis of protein is an amino acid supply route in Ras-transformed cells. Nature 497: 633-637, 2013.

41. Florey $\mathrm{O}$ and Overholtzer M: Macropinocytosis and autophagy crosstalk in nutrient scavenging. Philos Trans R Soc Lond B Biol Sci 374: 20180154, 2019.

42. Palm W, Park Y, Wright K, Pavlova NN, Tuveson DA and Thompson CB: The utilization of extracellular proteins as nutrients is suppressed by mTORC1. Cell 162: 259-270, 2015.

(i) (-) This work is licensed under a Creative Commons Attribution-NonCommercial-NoDerivatives 4.0 International (CC BY-NC-ND 4.0) License. 